\title{
General Practice in the United Kingdom - A training evolution
}

\author{
A evolução do treinamento em Medicina de Família no Reino Unido

\section{La evolución del entrenamiento en medicina familiar en el Reino Unido}

Patrick Hutt. GP Principal Queensbridge Group Practice (London) \& Clinical Associate Department of Primary Care and Population Health, University

College London (UCL). United Kingdom. patrick.hutt@nhs.net (Corresponding author)

\section{Abstract}

This article will outline the current state of training for UK General Practice, specifying some of the steps that must be taken in order to qualify, the challenges that trainees often face, and the career opportunities that may await them once completed. A historical perspective will be used to demonstrate the extent to which General Practice has evolved during the last sixty years. A few of the examples and explanations used in this article are by necessity simplistic, designed to highlight key areas of UK general practice in a bid to encourage readers to explore further if they wish to do so.

\section{Resumo}

Este artigo descreve o contexto atual da formação do Médico de Família no Reino Unido, especificando os desafios que muitas vezes os residentes enfrentam, as oportunidades de carreira que os esperam, uma vez concluído seu treinamento, bem como, alguns dos passos que devem ser seguidos para que possam se qualificar como Médicos de Família. Será utilizada uma perspectiva histórica para demonstrar em que medida a prática da Medicina de Família evoluiu ao longo dos últimos 60 anos. Alguns dos exemplos e explicações usados neste artigo são necessariamente simplistas, a fim de destacar as principais áreas de medicina de família no Reino Unido em uma tentativa de incentivar os leitores a explorarem ainda mais 0 tema, caso desejem fazê-lo.

\section{Resumen}

Este artículo describe el contexto actual en la formación del médico de familia en el Reino Unido, detallando los retos que a menudo enfrentan los residentes, las oportunidades de carrera que ellos esperan una vez completado su entrenamiento, así como algunos de los pasos que ellos deben seguir para lograren habilitación como médicos de familia. Una perspectiva histórica será utilizada para demostrar de qué modo la práctica de la medicina familiar ha evolucionado en los últimos 60 años. Algunas de las explicaciones y ejemplos utilizados en este artículo son necesariamente simplistas con el fin de destacar las principales áreas de la medicina familiar en el Reino Unido en un intento de animar a los lectores a explorar el tema más a fondo, si desean hacerlo.

\section{Keywords:}

Family Practice

Education, Medical

Primary Health Care

Internship and Residency

\section{Palavras-chave:}

Medicina de Família e

Comunidade

Educação Médica

Atenção Primária à Saúde

Internato e Residência

\section{Palabras clave:}

Medicina Familiar y

Comunitaria

Educación Médica

Atención Primaria de Salud

Internado y Residencia 


\section{In the beginning...}

When looking back at the history of medicine, aspiring hospital consultants and surgeons in the UK might be tempted to draw a linear line from the present all the way back to Hippocrates and the Greek Island of Crete in the 4th Century BC. The Royal College of Physicians was founded in 1518 and the Royal College of Surgeons founded in 1505. The college of GPs, founded in 1952, was not granted royal stature until 1972. Nevertheless the concept of a family doctor has been present for a long time. The role of the generalist stems in part from the amalgamation of the apothecaries (herbalists who prescribed medicines) and the barber surgeons who carried out operations.

Arthur Conan Doyle (author of Sherlock Holmes) wrote in 1894, based on his own experiences as a qualified doctor, of doing house calls in East London in the book 'Round the Red Lamp', a ritual familiar to many community doctors today. At the turn of the 20th Century Britain began to ensure that there was healthcare provision on a far greater scale, often via a 'panel doctor' who was a general practitioner. The creation of the National Health Service (NHS) in 1948, enshrined the principle of healthcare for all and free at the point of delivery (celebrated in London's 2012 Olympic Opening Ceremony). Everyone was given the opportunity to register with a general practitioner. Nevertheless, there has always been a sentiment that to pursue a career in General Practice is to somehow have failed as a doctor. This attitude has thankfully reduced over time, which is in part a result of the way that undergraduate and postgraduate training has evolved.

\section{Medical Education}

Until the late 20th Century many UK doctors would qualify without having set foot in General Practice. The first three years of undergraduate training were traditionally done in the laboratory, dissection room, lecture theatres and seminar rooms. Students would spend the subsequent three years in hospital settings sitting their final examinations after three years. The brightest students might be allowed an opportunity to specialize in a laboratory-based discipline, helping to pave the way for a career in haematology or oncology, for example. An enquiry into medical careers led Lord Moran, then head of the Royal College of Physicians, to state in 1958, when asked whether hospital consultants and general practitioners were of equal worth, "No! Could anything be more absurd? I was Dean at St Mary's Hospital Medical School for 25 years, and all the people of outstanding merit, with few exceptions, aimed to get on the staff. It was the ladder off which they [general practitioners] fell." 1

Today many UK medical students have exposure to General Practice from their first few weeks in training. Sections of the undergraduate curriculum are now regularly delivered in the community. ${ }^{2,3}$ This has allowed students to gain exposure to chronic disease management, the interface between primary and secondary care, and practise their communication skills. Intercalated medical degrees, whereby a student will typically take a year out from their course, permit a range of options for greater in depth studies. While traditionally these courses were lab-based there are now options for students in the UK to study primary care and related disciplines. ${ }^{4}$

Greater exposure to community medicine during the undergraduate years means UK medical students have a better sense of what general practice involves. This arguably helps students to make more informed career decisions and to have a greater respect for their GP colleagues, even if a student decides on an alternative career path.

The Foundation Programme for junior doctors was introduced in 2005. It consists of two years (F1 and F2) of supervised medical practice, bridging the gap between undergraduate studies and specialty training programs, such as hospital medicine, general practice, or surgery. There are 21 Foundation Schools throughout the UK, helping to coordinate all the training rotations. Foundation Schools are a "conceptual group of organisations" 5 responsible for delivering the curriculum. They tend to involve an NHS based regional training organisation (e.g. Health Education England), hospitals and university medical schools.

In 2013 there were just over 7500 junior doctors in each of the two foundation years. ${ }^{6}$ During the second year of training it is common for doctors to spend four months in general practice (In 2013 over 40\% of F2 doctors spent a rotation in general practice). ${ }^{5}$ This allows trainees to see patients in a supervised manner - gaining a sense of what continuity of care, home visits and working within the primary care team might involve. 
Such placements can be challenging for junior doctors. While a newly qualified doctor might occupy a clerk-like role in the hospital setting (ordering bloods, coordinating discharges, reviewing patients with a clear management plan etc.) they can find themselves relatively exposed in general practice, having to think through a far wider range of presentations, often with a strong psychological component. Equally trainees can find that they gain a strong set of transferable skills, helping to meet that broader aims of foundation programme; "[...] clinical effectiveness, leadership and the decision-making responsibilities that are essential for hospital and general practice specialty training."7

It is during their second year of foundation training that UK doctors must decide on which specialty they wish to pursue; core surgical training, core medical training or general practice. By such a point a trainee may well have a better sense of what the different specialties involve, including general practice.

The foundation programme was introduced as part of wider reforms in postgraduate training, known as Modernising Medical Careers (MMC), which aimed to provide a clearer career path. The centralized applications for foundation posts replaced a more personalised model where by students often applied to work for a consultant they had trained under. Prior to the reforms it was possible to be more nomadic as a doctor, constructing a career which involved six month rotations in different hospital jobs (a process that could continue for some years) and during this time gaining clinical experience and getting a better sense of who they were as individuals. Doctors often decided to enter general practice having accrued years of experience elsewhere, bringing a depth of knowledge (e.g. psychiatry or child health) that could complement an existing primary care team. It is not impossible to make changes to career paths after the foundation years but there is arguably a little less room to manoeuver.

\section{Choosing general practice}

So why do people in the UK choose general practice? Choosing a particular career path in medicine is by definition a personal choice. Currently $47 \%(35,782)$ of UK doctors are General Practitioners, ${ }^{8}$ with a government target to make this $50 \%$ by 2015 . It is reported that upon leaving medical school $25 \%$ of newly qualified doctors choose general practice as their preferred career option, ${ }^{9}$ though figures from the foundation programme show that $36 \%$ of $\mathrm{F} 2$ doctors selecting further core training chose general practice (and that it was first choice for the overwhelming majority of them).$^{10}$ Some of the themes that crop up for choosing general practice are a commitment to the role, the earning potential, and compatibility with having a family.

In 1982, Ronald Gibson a GP and former chair of the British Medical Association, wrote when looking back at this career, "The three great qualities of a GP in any century are compassion, sympathy, and understanding: the ability to feel at one with a patient in an illness and to show him that, once having consulted his GP, he is no longer alone in his struggle." ${ }^{11}$ It is fair to say that general practice has gone through various stages of popularity. In 1965 GPs were so unhappy about their working conditions (they were poorly paid relative to their hospital colleagues and typically worked from poor premises) that the vast majority threatened to resign. Currently in the UK the profession is arguably in greater shape: career paths in general practice are diverse and government policy aims to consolidate the role of general practice as more conditions are looked after in the community. Though it remains a point of contention that $90 \%$ of health encounters in the UK occur in primary care ${ }^{12}$ but primary care attracts less than $10 \%$ of the health budget. ${ }^{13}$

\section{General practice specialty training}

Postgraduate training to become a general practitioner has changed significantly since the National Health Service was formed in 1948. It had been the case that once a doctor had completed medical school no formal training was required in order to work as a general practitioner. It was common for younger doctors, having spent some time in hospital medicine, to serve as apprentices to family doctors in order to learn the trade and eventually set up practice on their own, or join another doctor in partnership, often taking over from a retiring doctor.

During the 1960s the College of General Practitioners lobbied to highlight the importance of vocational training, although it was not until 1976 that it became a legal requirement for all GPs who wanted to run practices or set up new 
services to have undertaken vocational training. ${ }^{14}$ In 2008 it became compulsory for all new doctors entering general practice to complete a three-year training programme, involving an exit examination, and become members of the Royal College of General Practitioners (RCGP).

Today prospective GP trainees must apply to regional schools, via a central application process, in an area that they wish to undertake their general practice training. These schools were previously known as 'Deaneries' in England but have changed in name to Health Education England. They serve a similar function to the foundation schools, but differ in that they are not as closely aligned to universities. A detailed explanation of the national application process for GP training can be found at www.gprecruitment.org.uk. Currently GP specialty training (ST) consists of three years, though there are some programmes which include an additional fourth year. The RCGP is currently lobbying to extend GP training in line with other specialty training undertaken by physicians and surgeons. ${ }^{15}$

\section{ST1 and ST2 year}

It is during the ST1 and ST2 years that trainees rotate through different specialties. These rotations are made up of a combination of 3-6 month placements in a variety of specialties. The majority of the ST1 and ST2 years will be made up of exposure to Accident and Emergency Medicine, Paediatrics or Community Paediatrics, General Medicine, Obstetrics and Gynaecology, Psychiatry or Palliative Medicine. There is also scope for including time in subspecialties such as Public Health, Ophthalmology, or ENT (ears, nose, and throat). It can sometimes be a struggle to ensure that the combination of rotations is balanced. Trainees have to accept that they will not experience everything needed to equip them to become a GP - and the emphasis is on continual professional development throughout one's career.

One of the key themes is that ST1 and ST2 doctors are on a career path to become general practitioners. Although a trainee may be attached to an emergency medicine department/obstetric unit, they are there to gain skills to become independent community practitioners. An online curriculum, learning log, and the need to complete key competences, help trainees stay on track. Also important is keeping in contact with other GP trainees. Local training schemes typically have time tabled half days/whole days throughout the year facilitated by course organisers. ST1, 2, and 3 trainees are supposed to have protected time to meet, ensuring that a GP curriculum can be delivered and case discussions, relevant to primary care, can be debated.

\section{ST3 year}

The ST3 year is similar to that of an apprentice many years ago. Trainees are assigned a trainer and a practice for twelve months. During this time trainees see patients in a community setting. Typically trainees start with 30-minute consultations, discussing most cases before the patient leaves, working towards 10-minute consultations and being relatively independent in the majority of management decisions by the end of the year. It is a steep learning curve. During the course of the ST3 year trainees typically undertake the examinations that are required to pass the Membership of the Royal College of General Practitioners, namely the Clinical Skills Assessment (CSA), a half-day simulated surgery (involving actors as patients) designed to reflect a typical morning or afternoon in general practice, and the Applied Knowledge Test (AKT), which involves multiple choice questions designed to see how well trainees can apply their knowledge. There is also an array of activities that must be undertaken as part of the e-portfolio, such as: getting satisfaction ratings from patients and colleagues, out of hours sessions (e.g. at the weekend or late in the evening), and reflecting on and writing up cases discussed with the GP trainer.

Current ST3 years are arguably a lot more supportive than the experience of David Morell, who wrote of his trainee year in 1957, "My vocational training lasted three days, because one of the partners [managing doctors] was in desperate need of a holiday and left a week after my arrival." ${ }^{16}$ Dr Mareeni Raymond, a GP, reflected on her ST3 training experience. "Overall the year was challenging, as learning how to consult effectively, multitask managing the paperwork and results I received daily, as well as the anxieties that come with particular types of high risk patients, was very difficult to do at the time. On the plus side, general practice proved to be a much better learning environment for me than my previous posts." ${ }^{17}$ 
There is a lot to get through during the ST3 year and trainees often feel overwhelmed, particularly with the sense of having to do the work of looking after patients and at the same time record and reflect on the experience for the e-portfolio. This demand does not fully disappear once qualified in the UK as the appraisal process, a requirement for all practicing GPs, to keep a log of their learning activities throughout the year.

There are a limited number of ST4 posts which allow a select number of trainees to undertake further training in leadership positions, public health, academia and teaching. These posts are relatively new and allow trainees to develop particular skills sets whilst cementing their clinical knowledge by remaining attached to a GP practice. The RCGP and The British Medical Association (BMA) would like to see GP training extended to five years in line with hospital and surgical training.

\section{Qualified decisions}

The number of career paths within UK general practice is incredibly diverse. The traditional model for GPs, which persists today, is that of running a practice either on your own or, more often, with a number of other colleagues in partnership. In such instance the GP is responsible for the day-to-day management of the staff, premises and patient care. When the NHS was founded GPs maintained their independent contractor status and therefore operate as small businesses. For doctors who are keen to commit to a particular area and like the leadership challenge of delivering services, partnership can be particularly appealing. The other major permutation is working as a salaried GP, where a doctor is contracted to work a fixed number of clinical sessions during the week. This often permits clinicians to focus on providing clinical care rather than worrying about a leaking roof or whether there will be enough money to pay staff if there is a delay in receiving a payment from the local authority. Both forms of working, partnership and salaried, have their merits. Which appeals more will depend on the circumstances of an individual as well as what is available locally. In recent years partnerships have been better remunerated financially and in shorter supply, though this trend may be changing as government reforms make some partnerships financially unviable.

For doctors wishing to have more flexibility there are many who undertake locum work, which is done on a shortterm basis (often deputising for doctors or where there are staff shortages). There are also some doctors by whom most of their work is undertaken in out of hours services, typically at the weekend/late in the evening ensuring that healthcare is accessible in the NHS 24 hours a day. It is now also common for GPs to develop sub specialties in family planning, ENT, or dermatology - allowing them to have an increasing portfolio career. Since the 1970s academic general practice has gained in stature and the reforms in medical training mean that GPs wishing to develop teaching and research skills can do so, combining medical practice with academic positions. There is also a tradition of GPs entering public health medicine and also using their transferable skill set overseas.

\section{Conclusions}

UK general practice training has evolved significantly over the last 100 years, which is probably true of all disciplines in medicine but especially true of general practice. It remains a rewarding career path for many, although the challenges facing modern health services mean that the status quo can only exist momentarily: further reforms and challenges are inevitable. UK general practice has established itself as a cornerstone of UK health service provision. In a globalized world it is important that countries continue to learn from each other, sharing examples of innovations from which many can learn. High quality primary care, both in the UK and around the world, is essential to ensure that the health needs of populations are appropriately met equitably and cost effectively.

\section{Acknowledgements}

I would like to thank Dr Joe Rosenthal and Jo McGovern for their helpful comments on this article. 


\section{References}

1. Curwen M. Lord Moran's Ladder. J Coll Gen Pract. 1964; 7(1): 38-65 [online] [cited 2014 Jan 18]. Available from: http://www.ncbi.nlm.nih.gov/pmc/ articles/PMC1878217/

2. University College London. UCL Research Department of Primary Care and Population Health. Community Based Teaching [online]. Available from: http://www.ucl.ac.uk/pcph/undergrad/cbt

3. Queen Mary Medical School. Institute of Health Sciences Education. Community Based Medical Education. [online]. Available from: http://qmplus. qmul.ac.uk/course/view.php?id=2605

4. Jones M, Hutt P, Eastwood S, Singh S. Impact of an intercalated BSc on medical student performance and careers: a BEME systematic review: BEME Guide No. 28. Medical Teacher. 2013; 35(10): e1493-510. http://dx.doi.org/10.3109/0142159X.2013.806983

5. UK Foundation Programme Office. What are Foundation Schools? [online]. Available from: http://www.foundationprogramme.nhs.uk/pages/home/ deaneries-foundation-schools

6. UK Foundation Programme Office. Foundation Programme Annual Report 2013 UK Summary [online]. UK Foundation Programme Office; Nov 2013. p. 4-13 [cited 2014 Jan 18]. Available from: http://www.foundationprogramme.nhs.uk/index.asp?page=home/keydocs\#fpar

7. UK Foundation Programme Office. Foundation Programme [online]. Available from: http://www.foundationprogramme.nhs.uk/pages/home/aboutthe-foundation-programme

8. Jaques H. Number of consultants surges while that of GP partners falls. BMJ Careers. 2013 Mar 21 [online]. Available from: http://careers.bmj.com/ careers/advice/view-article.htm?id=20011384

9. Svirko El, Goldacre M, Lambert T. Career choices of the United Kingdom medical graduates of 2005, 2008 and 2009: Questionnaire surveys. Medical Teacher. 2013; 35(5): 365-375. http://dx.doi.org/10.3109/0142159X.2012.746450

10. UK Foundation Programme Office. F2 Career Destination Report 2013 [online]. [cited 2014 Jan 14]. Available from: http://www.foundationprogramme. nhs.uk/pages/home/keydocs

11. Gibson R. The Family Doctor: His Life and History. Allen and Unwin; 1981. p. 9.

12. Kings Fund. Improving the quality of care in General Practice: report of an independent inquiry. The Kings Fund; 2011.

13. British Medical Association - BMA. GP Committee, Developing General Practice Today, Providing Healthcare Solutions for the Future. BMA; 2013 [online] [cited 2014 Jan 14]. Available from: http://bma.org.uk/working-for-change/negotiating-for-the-profession/bma-general-practitioners-committee/ priorities/gpc-vision

14. Tait I. History of the College. Royal College of General Practitioners; 2002 [online]. Edited and Updated by the Archivist, March 2012. [cited 2014 Jan 7]. http://www.rcgp.org.uk/about-us/history-heritage-and-archive/history-of-the-college.aspx

15. Shape of Training. Shape of Training Final Report [online]. Available from: www.shapeoftraining.co.uk/reviewsofar/1788.asp

16. Morrell D. Introduction and Overview. In: Loudon I, Horder K, Webster C, editors. General Practice under the National Health Service $1948-1997$. Oxford: Claredon Press; 1998. http://dx.doi.org/10.1093/acprof:oso/9780198206750.003.0001

17. Raymond M, Rosenthal J. General Practice Specialty Training. In: Hutt P, Park S, editors. A Career Companion to Becoming a GP. Oxford: Radcliffe Publishing; 2011. p. 32. 